\title{
Fanconi and Inappropriate Secretion of Antidiuretic Hormone Syndromes Secondary to Venlafaxine Therapy
}

\author{
Hassane Izzedine Vincent Launay-Vacher Magali Ciroldi Laurence Fardet \\ Gilbert Deray
}

Department of Nephrology, Pitié-Salpêtrière Hospital, Paris, France

Venlafaxine, a 2-phenyl-2 (1-hydroxycycloalkyl) ethylamine derivate, is an inhibitor of both serotonin and norepinephrine re-uptake and was termed a 'dual uptake inhibitor' [1]. We report on a venlafaxine-treated patient who developed Fanconi's syndrome (FS) and hyponatremia secondary to inappropriate antidiuretic hormone secretion syndrome (SIADH).

\section{Case Report}

An 82-year-old woman with chronic alcohol abuse, hyponatremia $(128 \mathrm{mmol} / \mathrm{l})$, and essential hypertension treated by atenolol $50 \mathrm{mg}$ daily was admitted to hospital for depression. On examination, she presented with anxiety disorder and mental confusion. She had no fever and blood pressure and heart rate were 120/80 $\mathrm{mm} \mathrm{Hg}$ and 85 beats/min, respectively. Neither dehydration nor edema was noted. Despite incoherent speaking, no localizing neurological signs of meningitis were observed. Her serum sodium level was $128 \mathrm{~mm} / 1$, potassium $4.4 \mathrm{mmol} / \mathrm{l}$, chloride $94 \mathrm{mmol} / \mathrm{l}$, total carbon dioxide $28 \mathrm{mmol} / \mathrm{l}$, blood urea $5.2 \mathrm{mmol} / \mathrm{l}$, serum creatinine $82 \mu \mathrm{mol} / 1$, serum uric acid $388 \mu \mathrm{mol} / 1$, calcium $2.4 \mathrm{mmol} / \mathrm{l}$, phosphate $1.2 \mathrm{mmol} / 1$, and glucose level $5.2 \mathrm{mmol} / \mathrm{l}$, and anion gap $14 \mathrm{mmol}$. Urinalysis revealed $\mathrm{a}++$ glycosuria, ++ proteinuria, and urine $\mathrm{pH}$ at 5 . Chest $\mathrm{X}$-ray, cerebral computer angiotomography scan were normal as for adrenal, thyroid tests, and liver function. Urine osmolality, sodium, potassium, and urea were $370 \mathrm{mosm} / \mathrm{kg}, 60 \mathrm{mmol} / 1,20 \mathrm{mmol} / \mathrm{l}$, and $210 \mathrm{mmol} / \mathrm{l}$, respectively.

The patient was treated with venlafaxine $50 \mathrm{mg}$, twice daily. Four days after the start of treatment, electrolytes were sodium $111 \mathrm{mmol} / \mathrm{l}$, potassium $3.7 \mathrm{mmol} / \mathrm{l}$, chloride $85 \mathrm{mmol} / \mathrm{l}$, total carbon dioxide $19 \mathrm{mmol} / \mathrm{l}$, blood urea $2.8 \mathrm{mmol} / 1$, serum creatinine $37 \mu \mathrm{mol} / 1$, serum uric acid $58 \mu \mathrm{mol} / 1$, serum phosphate $0.49 \mathrm{mmol} / 1$, serum glucose $4.5 \mathrm{mmol} / \mathrm{l}$, and anion gap $14 \mathrm{mmol}$ with urine $\mathrm{pH}$ at 6.5 and glycosuria in spite of normal glycemia. Serum ADH level was $2.5 \mathrm{IU} / \mathrm{ml}$ (normal range $0.5-1.5$ ) and plasma and urine osmolality were 238 and $390 \mathrm{mosm} / \mathrm{kg}$, respectively. Acquired Fanconi's syndrome and SIADH induced by venlafaxine were diagnosed. The patient required hydric restriction, isotonic saline solution infusion $(500 \mathrm{ml} /$ day $)$ and venlafaxine was withdrawn. After 2 days, electrolyte levels improved and were total carbon dioxide $26 \mathrm{mmol} / \mathrm{l}$, serum uric acid $100 \mu \mathrm{mol} / \mathrm{l}$, and serum phosphate $0.99 \mathrm{mmol} / \mathrm{l}$. One week after venlafaxine was withdrawn, serum sodium was $130 \mathrm{mmol} / \mathrm{l}$. The patient's condition gradually improved and she was discharged after 2 weeks having fully recovered her normal baseline mental status.

\section{KARGER \\ Fax +41613061234 E-Mail karger@karger.ch www.karger.com \\ (C) 2002 S. Karger AG, Basel 0028-2766/02/0924-0944\$18.50/0 \\ Accessible online at: www. karger.com/journals/nef}

Hassane Izzedine, MD

Department of Nephrology, Pitié-Salpêtrière Hospital

83, boulevard de l'Hôpital, F-75013 Paris (France)

Tel. +3314217 72, 29, Fax +33142177232

E-Mail hassan.izzedine@psl.ap-hop-paris.fr 
Table 1. Reports of venlafaxine-induced hyponatremia

\begin{tabular}{|c|c|c|c|c|c|c|}
\hline \multirow[t]{2}{*}{ Author } & \multirow{2}{*}{$\begin{array}{l}\text { Patient } \\
\text { age/sex }\end{array}$} & \multicolumn{2}{|l|}{ Venlafaxine use } & \multicolumn{3}{|l|}{ Hyponatremia } \\
\hline & & indication & $\begin{array}{l}\text { dosage } \\
\mathrm{mg} / \text { day }\end{array}$ & $\begin{array}{l}\text { time between } \\
\text { venlafaxine introduction } \\
\text { and diagnosis }\end{array}$ & $\begin{array}{l}\text { time between } \\
\text { venlafaxine withdrawal } \\
\text { and trouble correction }\end{array}$ & mechanism \\
\hline Gupta and Saravay [3], 1997 & $76 / \mathrm{F}$ & $\begin{array}{l}\text { depression and } \\
\text { associated anxiety }\end{array}$ & 50 then 75 & 1 week & 1 week & SIADH \\
\hline Meynaar et al. [4], 1997 & $65 / \mathrm{M}$ & presumed depression & 75 & 1 week & 2 weeks & SIADH \\
\hline Ranieri et al. [5], 1997 & $79 / \mathrm{F}$ & depression & - & - & - & ROS \\
\hline Masood et al. [2], 1998 & $92 / \mathrm{F}$ & depression & 75 & - & few weeks & SIADH \\
\hline Our patient & $82 / \mathrm{F}$ & $\begin{array}{l}\text { depression and } \\
\text { associated anxiety }\end{array}$ & 50 then 100 & 2 days & 4 days & SIADH \\
\hline
\end{tabular}

SIADH = Syndrome of inappropriate antidiuretic hormone secretion; ROS = reset osmostat syndrome.

\section{Discussion}

Venlafaxine is a serotonin re-uptake inhibitor that inhibits not only serotonin but also norepinephrine reuptake. Clinically significant hyponatremia has been reported as a side effect of its utilisation [2] by SIADH [3, 4]. and reset osmostat syndrome [5].

Our patient had a history of chronic alcohol abuse and essential hypertension treated with atenolol. It is well known that hyponatremia is commonly reported in chronic alcoholic patients (17.3\%) [6] and has been attributed to hypovolemia, pseudohyponatremia with alcoholinduced severe hypertriglyceridemia, 'beer potomania syndrome' and reset osmostat syndrome (ROS) or cerebral salt wasting syndrome. On admission, our patient did not present any clinical symptoms of extracellular dehydration or hyperhydration. Furthermore, serum triglyceride, glucose, protide levels were normal at $1 \mathrm{mmol} / \mathrm{l}$, $5 \mathrm{mmol} / 1$, and $70 \mathrm{~g} / 1$, respectively.

The syndrome of 'beer potomania' hyponatremia is due to a large consumption of beer together with a minimal intake of ordinary food such as in our patient. However, beer drinkers typically produce less than 250 mosm of solutes a day, and urine osmolality in our patient at admission was higher than 350 mosm. We thus believe that initial hyponatremia in our patient was due to a reset osmostat syndrome variant of SIADH because of a chronic asymptomatic hyponatremia of moderate severity $(125-130 \mathrm{mmol} / \mathrm{l})$ and that it was not corrected with adequate sodium chloride loading $(130 \mathrm{mmol} / \mathrm{l})$. The typical features of SIADH are hyponatremia, low serum osmolality, high urine osmolality and urine sodium excre- tion which is inappropriately high with regard to serum sodium concentration.

The risk of SIADH secondary to antidepressant drugs seems to be higher in the first few weeks of treatment [7]. Several cases of venlafaxine-induced hyponatremia have been reported in the literature (table 1). The development of hyponatremia appears within a week after the start of venlafaxine therapy. Our patient developed acute hyponatremia 2 days later. Return to baseline serum sodium level after treatment is withdrawn requires a few days with a gradually mental status improvement such as in our patient. In Australia, the Adverse Drug Reactions Advisory Committee has received 234 reports of suspected adverse reactions in association with this drug [8]. Fifteen reports of hyponatremia were detected between 3 and 20 days (median 9) after initiation of therapy, with minimum values of serum sodium concentrations ranging from 116 to $130 \mathrm{mmol} / \mathrm{l}$ (median 124). Associated symptoms including confusion (3 cases), syncope, nausea, fatigue, hallucination, agitation, convulsions, delirium, and ataxia were reported in 7 cases. SIADH was suspected in 7 reports but was confirmed in only 1 . This adverse effect seems to be dose dependent: asymptomatic hyponatremia with a 50-mg daily dosage and neurologic and psychiatric symptoms at a $75 \mathrm{mg}$ or more daily dosage [3]. Medication management includes venlafaxine withdrawal, fluid restriction, and infusion of normal saline. In some cases, the use of furosemide, along with careful monitoring of her intake and output has been recommended.

Venlafaxine has been shown to induce hyponatremia (table 1) particularly in patients whose sodium reserve has been depleted because of dietary restriction or diuretic 
use. However, its effect on proximal tubular is unknown, and the real mechanism of venlafaxine-induced Fanconi's syndrome remains unclear. The acute combination of normal anion gap metabolic acidosis with alkaline urine $\mathrm{pH}$ (of renal tubular origin), glycosuria in spite of normal serum glucose, low serum uric acid and phosphate concentrations and hypokaliemia are highly suggestive of acquired Fanconi's syndrome.
All abnormalities in our patient were transient, with recovery occurring 4 days after venlafaxine withdrawal.

Physicians should keep in mind the possible occurrence of or be alerted to the possibility of SIADH and Fanconi's syndromes induced by venlafaxine. Therefore, tubular function, electrolytes and acid-base statements should be monitored in patients treated with venlafaxine.

\section{References}

1 Holliday SM, Benfield P: Venlafaxine: A review of its pharmacology and therapeutic potential in depression. Drugs 1995;49:280-294.

2 Masood GR, Karki SD, Patterson WR: Hyponatremia with venlafaxine. Ann Pharmacother 1998;32:49-51.

3 Gupta AK, Saravay SM: Venlafaxine-induced hyponatremia. J Clin Psychopharmacol 1997; 17:223-225.
4 Meynaar IA, Peeters AJ, Mulder AH, Ottervanger JP: Syndrome of inappropriate ADH secretion attributed to the serotonin re-uptake inhibitors, venlafaxine and paroxetine. Neth J Med 1997;50:243-245.

5 Ranieri P, Franzoni S, Rozzini R, Trabucchi $\mathrm{M}$ : Venlafaxine-induced reset osmostat syndrome: Case of a 79-year-old depressed woman. J Geriatr Psychiatry Neurol 1997;10:7578.
6 Liamis GL, Milionis HJ, Rizos EC, Siamopoulos KC, Elisaf MS: Mechanisms of hyponatraemia in alcohol patients. Alcohol Alcohol 2000;35:612-616.

7 Spigset O, Hedenmalm K: Hyponatraemia and the syndrome of inappropriate antidiuretic hormone secretion (SIADH) induced by psychotropic drugs. Drug Saf 1995;12:209-225.

8 Boyd IW: Comment: Hyponatremia with venlafaxine. Ann Pharmacother 1998;32:981982. 